\title{
Ceragenins - a new weapon to fight multidrug resistant bacterial infections
}

\section{Cerageniny - nowe perspektywy w zwalczaniu infekcji wywołanych przez wielooporne szczepy bakteryjne}

\author{
Urszula Surel'1, Katarzyna Niemirowicz¹, Michal Marzec², Paul B. Savage ${ }^{3}$, Robert Bucki ${ }^{1,4}$ \\ ${ }^{1}$ Department of Microbiological and Nanobiomedical Engineering, Medical University of Bialystok, Bialystok, Poland \\ Head of Department: Prof. Adam Krętowski \\ ${ }^{2}$ Department of Pathology and Laboratory Medicine, University of Pennsylvania, Philadelphia, PA, USA \\ Head of Department: Prof. David B. Roth \\ ${ }^{3}$ Department of Chemistry and Biochemistry, Brigham Young University, Provo, UT, USA \\ Head of Department: Prof. Greg Burton \\ ${ }^{4}$ Department of Pathophysiology and Infection Microbiology, Institute of Nursing and Obstetrics, Faculty of Health Sciences, \\ Jan Kochanowski University, Kielce, Poland \\ Head of Department: Prof. Stanisław Głuszek MD, PhD
}

Studia Medyczne 2014; 30 (3): 207-213

Key words: microbiology, antibacterial activity, cationic lipids.

Słowa kluczowe: mikrobiologia, aktywność przeciwbakteryjna, lipidy kationowe.

\begin{abstract}
Growing antibiotic resistance among pathogenic microorganisms is one of the most challenging problems. Often, a single mutation in a bacterial cell leads to the formation of a new drug resistance mechanism. The ceragenins are a novel class of antibiotic, offering great promise in future treatment of infections. These cationic antimicrobial lipids are net positively charged cholic acid derivates that are electrostatically attracted to the negatively charged membranes of bacteria, certain viruses, fungi, and protozoa. After membrane insertion, they interfere with membrane organisation, resulting in membrane dysfunction and cell death. This review focuses on the broad spectrum of antibacterial activity of ceragenins, and their potential to become a new group of antibiotics for prevention and treatment of infections, especially those caused by multidrug-resistant bacteria.
\end{abstract}

\section{Streszczenie}

Stale narastająca oporność bakterii na antybiotyki jest jednym z najtrudniejszych problemów. Często pojedyncza mutacja w komórce bakteryjnej prowadzi do powstania i rozwoju nowego mechanizmu, nadającego bakteriom oporność na antybiotyki. Cerageniny (pochodne kwasu cholowego) są analogami naturalnych kationowych peptydów przeciwbakteryjnych oferujących nowe możliwości w leczeniu infekcji bakteryjnych. Mają one dodatni ładunek powierzchniowy, dzięki czemu oddziałuja elektrostatycznie z negatywnie naładowana powierzchnią bakterii, wirusów, grzybów i pierwotniaków. Po insercji w strukturę lipidową błony mikroorganizmów zaburzają jej funkcję, co w efekcie prowadzi do śmierci komórki. W niniejszej pracy przedstawiono szerokie spektrum aktywności przeciwdrobnoustrojowej ceragenin i ich potencjał w zwalczaniu infekcji, w szczególności powodowanych przez wielooporne szczepy bakteryjne.

\section{Multidrug-resistance}

The widespread inappropriate use of antibiotics is considered the major factor driving the increasing number of multidrug-resistant bacterial strains. Antibiotic treatment is very often prescribed as a preventative treatment and is given with disregard to the importance of the commensal microbiota that colonise the skin, gut, and mucosal surfaces of the human body [1]. According to the U.S. Center for Disease Control and Prevention (CDC), every year drug-resistant bacteria infect more than two million people nation- wide, and a large percentage of those infections occur with involvement of multidrug-resistant bacteria. Additionally, some of those infections are acquired in health care facilities (health care-associated infections, HCAIs). Multidrug-resistant pathogens usually cause infections in more vulnerable individuals, especially immunocompromised and immunosuppressed patients, and those with burn injuries, cancer, or genetic disorders such as cystic fibrosis (CF) or Down's syndrome [2, 3]. Drug resistance is considered the most important cause of expansion of tuberculosis 
in the modern world. In the European Region of the World Health Organisation (WHO) a total of $15.7 \%$ of new and $45.3 \%$ of previously treated tuberculosis (TB) cases are estimated to be caused by multidrug-resistant tuberculosis (MDR-TB). Drug-resistant TB (XDRTB) (resistance to fluoroquinolones and second-line injectables) has been reported extensively in 38 of the 53 countries of the region $(72 \%)[4,5]$. In addition, there are an increasing number of reported infections caused by multidrug-resistant Escherichia coli, Klebsiella pneumoniae, Staphylococcus aureus, Vibrio cholera, and non-typhoid Salmonella in different African countries [6]. Some Asian countries have become epicentres of resistance, having seen rapid increases in the prevalence of antimicrobial resistance of major bacterial pathogens (MRSA, macrolide-resistant Streptococcus pneumoniae, and multidrug-resistant Enterobacteriaceae) with very high rates of HCAIs [7, 8]. Latin America has a high rate of community-associated infections caused by multidrug-resistant Enterobacteriaceae relative to other world regions. Urinary tract infections (UTIs) by E. coli, and intra-abdominal infections (IAIs) by E. coli and K. pneumoniae, are characterised by high rates of resistance to trimethoprim/sulphamethoxazole, quinolones, and second-generation cephalosporins [9]. In response to the global public health threat posed by resistant pathogens a number of national and international actions and initiatives have been developed [10]. Although the most effective strategy to reduce the incidence of infections caused by multidrug-resistant bacteria has not yet been established, a multifaceted method is will probably be most effective, including actions aimed at optimising antibiotic use, increasing surveillance and infection control, and improving healthcare worker training and public education with regard to unanticipated consequences of antibiotic use [10]. Research should be focused on bringing new effective antibiotics, antibiotic-antibiotic combinations, and the development of adjuvants that either directly target resistance mechanisms ((such as inhibition of $\beta$-lactamase enzymes) or indirectly target resistance by interfering with bacterial signalling pathways (similarly to two-component systems (TCSs)) [11]. Design of new bactericidal molecules should be based on two fundamental principles. First, the new agents should target simple but fundamental properties of the bacteria, which would render resistance much more difficult to develop. Second, the antimicrobial agents should have anti-biofilm properties [12].

\section{Ceragenins}

Produced by shark Squalus acanthias and described in 1993, squalamine is considered to be the first natural representative of the ceragenin family (Figures $1 \mathrm{~A}$ and $1 \mathrm{~B})$. It exhibits potent bactericidal activity against both Gram-negative and Gram-positive bacteria. Furthermore, it is fungicidal by inducing osmotic lysis of the protozoa cell. The discovery of squalamine in the shark implicates a steroid molecule as a potential host-defence agent in vertebrates and provides insight into the chemical design of a family of broad-spectrum antibiotics [13]. In contrast to the sterol nature of fish squalamine, all mammals are equipped with cationic antibacterial peptides (CAPs) that represent the first line of defence against invasive pathogens [14, 15]. Physicochemical properties of squalamine and CAPs are similar because both are amphiphilic with net positive charge. Both are attractive candidates for clinical development of new antibiotics for three reasons: 1) a non-specific ability to induce dysfunction of the membranes of the pathogen (membrane permeabilisation and depolarisation), 2) speed of action, and 3) the difficulty of bacteria to develop a resistance mechanism [16-20].

The advantageous properties of squalamine and CAPs were used in the development of a new class of synthetic antibacterial molecules including ceragenins. Ceragenins are cholic acid derivates [16] that are similar in antibacterial activity to condensed amino acid (derivatives of cholic acid marked with L-arginine), which was first synthesised in 1979 [21]. Like antibacterial peptides [22, 23], ceragenins display positive charges arranged on one face and hydrophobic residues on the other [16]. Ceragenins are also known as cationic steroid antibiotics (CSAs) and can be separated into two categories: polymyxin mimics, and squalamine and its mimics. Polymyxin mimics are characterised structurally by the attachment of three amine groups, via tethers, to a steroid nucleus. The second group consists of squalamine and its mimics, where the position of the polyamine and sulphate groups are reversed. Squalamine and its mimics can accept facially amphiphilic conformations in the presence of membrane molecules by passing the polyamine chain common to these compounds over the face of the steroid [24, 25]. CSA-13 is a lead compound from the ceragenin family, which is relatively simple to prepare and purify at a low cost $[17,19]$. The broad spectrum of CSA-13 antibacterial activity includes activity against multidrug-resistant $P$. aeruginosa [26], vancomycin-resistant S. aureus [27] H. pylori [28], carbapenem-resistant Acinetobacter baumannii [29], and periodontopathic bacteria such as Streptococcus mutans and Porphyromonas species [30] (Table 1). Significant activity of CSA-13 against cariogenic and periodontopathic bacteria correlate with its ability to bind bacteria lipopolysaccharide and lipoteichoic acid linked to erythrocytes [30]. CSA-13 is also active against vaccinia virus (VV) [31] and Trypanosoma cruzi [32]. Although some forms of ceragenins are effective against both Gram-negative and Gram-positive bacteria, they are generally more potent against Gram-positive bacteria (Figures $1 \mathrm{C}$ and $1 \mathrm{D}$ ). Surprisingly, it is 
not the cell wall, but the high content of phosphatidylethanolamine in most Gram-negative bacteria that provide them with resistance [17]. Ceragenins with a hydrophobic chain are bactericidal at low concentrations and match the antibacterial activity of polymyxin B against Gram-positive bacteria [24]. Recently, antimicrobial nanoparticles were synthesised using ceragenins and they were introduced as multifunctional theranostics [33]. Different applications of ceragenins include contact lenses, hydrogels with an antibacterial innate immune function [34], polymeric coating applied to implanted devices to prevent perioperative device-related infections [35], thermally, chemically, and physically stable medical grade polydimethylsiloxane (PDMS) material to prevent biofilm formation [36], silicon [37], and gene delivery systems [38] (Figure 2). Similarly to cathelicidin-related antimicrobial peptides [15], ceragenins that mimic the hydrophobic and cationic morphology of cathelicidin have antiproliferative effects on the colon cancer-derived cell line HCT116. Addition of CSA-13 to a cell culture of HCT116 cells arrested cell growth, increasing the incidence of apoptosis detected by the binding of annexin $\mathrm{V}$, and mitochondrial membrane depolarisation. More precisely, cell-cycle analysis showed that the CSA-13-treated wild-type and p53 null mutant HCT116 cell growth was arrested at the G1/S phase, indicating that CSA-13 affects the cell cycle through a p53-independent pathway. This finding suggests that the membrane-permeabilising capability is the common underlying mechanism for both the anticancer and antimicrobial effects of CSA-13 [39]. CSA-13 shows low toxicity in animal studies, supporting this compound's possible application in human treatment [40]. However, ceragenins and CAPs may be restricted to topical applications due to low activity in blood plasma [20]. Ceragenin molecules are advantageous over cationic amphipathic peptides due to their protease resistance. They also incorporate stably into membranes and have the unusual property of forming complexes with phospholipids [17].

\section{Ceragenins in treatment of cystic fibrosis lung infections}

Cystic fibrosis is an autosomal-recessive genetic disease caused by mutations in the cystic fibrosis transmembrane conductance regulator (CFTR) gene of chromosome 7. Chronic lung infections caused in about $70 \%$ of $\mathrm{CF}$ adult patients by $P$. aeruginosa are the major cause of death in the course of CF lung disease. Treatment of lung infections to reduce inflammation and lung injury is of major importance in the management of CF. The CF individuals are extremely susceptible to bacterial infections of the respiratory tract due to very viscous, dehydrated sputum accumulating in the airways. Frequent and intensive antibiotic therapy is required to maintain lung function, to increase
Table 1. Susceptibility of selected bacteria strains to CSA13 administration expressed as minimal inhibitory concentration (MIC)

\begin{tabular}{|c|c|c|}
\hline $\begin{array}{l}\text { Bacteria strain } \\
\text { ( }{ }^{*} \text { clinical isolate) }\end{array}$ & $\begin{array}{c}\mathrm{MIC} \\
{[\mathrm{mg} / \mathrm{ll}]}\end{array}$ & Ref. \\
\hline Staphylococcus aureus MRSA & 0.5 & {$[20]$} \\
\hline Staphylococcus aureus VISA & 1 & {$[20]$} \\
\hline Staphylococcus aureus VRSA & 1.1 & {$[20]$} \\
\hline $\begin{array}{l}\text { Staphylococcus aureus ATCC } \\
25923 \text { VRSA }\end{array}$ & 0.4 & {$[18]$} \\
\hline $\begin{array}{l}\text { Staphylococcus aureus ATCC } \\
25923\end{array}$ & 0.3 & {$[18]$} \\
\hline $\begin{array}{l}\text { Streptococcus salivarius ATCC } \\
13419\end{array}$ & 0.7 & [44] \\
\hline $\begin{array}{l}\text { Streptococcus mutans ATCC } \\
35668\end{array}$ & 0.7 & {$[44]$} \\
\hline Staphylococcus epidermidis* & 0.35 & {$[44]$} \\
\hline Streptococcus pneumoniae* & 0.35 & {$[44]$} \\
\hline Streptococcus pyogenes* & 0.7 & {$[44]$} \\
\hline $\begin{array}{l}\text { Lactobacillus } \\
\text { casei ssp. casei ATCC } 393\end{array}$ & 22.4 & {$[44]$} \\
\hline Staphylococcus aureus Xen 29 & 1.4 & {$[44]$} \\
\hline $\begin{array}{l}\text { Enterococcus faecalis } \\
\text { ATCC } 29212\end{array}$ & 2.8 & {$[44]$} \\
\hline Haemophilus influenzae ${ }^{*}$ & 0.35 & {$[44]$} \\
\hline $\begin{array}{l}\text { Moraxella catarrhalis } \\
\text { ATCC } 23246\end{array}$ & 1.4 & {$[44]$} \\
\hline Helicobacter pylori* & 0.7 & {$[44]$} \\
\hline $\begin{array}{l}\text { Pseudomonas aeruginosa Xen } 5 \\
\text { Pseudomonas aeruginosa }\end{array}$ & $\begin{array}{c}5.6 \\
2\end{array}$ & $\begin{array}{l}{[44]} \\
{[52]}\end{array}$ \\
\hline $\begin{array}{l}\text { Pseudomonas aeruginosa } \\
\text { ATCC } 27853\end{array}$ & 2 & {$[18]$} \\
\hline Pseudomonas aeruginosa $316^{\star}$ & 4 & {$[26]$} \\
\hline Pseudomonas aeruginosa $711^{\star}$ & 8 & {$[26]$} \\
\hline Pseudomonas aeruginosa $727^{\star}$ & 1 & {$[26]$} \\
\hline Pseudomonas aeruginosa R1130 & 4 & {$[26]$} \\
\hline Neisseria meningitidis (B) & 0.7 & {$[44]$} \\
\hline Neisseria meningitidis (C) & 0.7 & {$[44]$} \\
\hline $\begin{array}{l}\text { Acinetobacter baumannii } \\
\text { ATCC } 19606\end{array}$ & 3 & {$[18]$} \\
\hline Acinetobacter baumannii & 1.6 & [29] \\
\hline Pseudomonas cangingivalis & 3.2 & {$[30]$} \\
\hline Pseudomonas circumdentaria & 0.8 & [30] \\
\hline
\end{tabular}




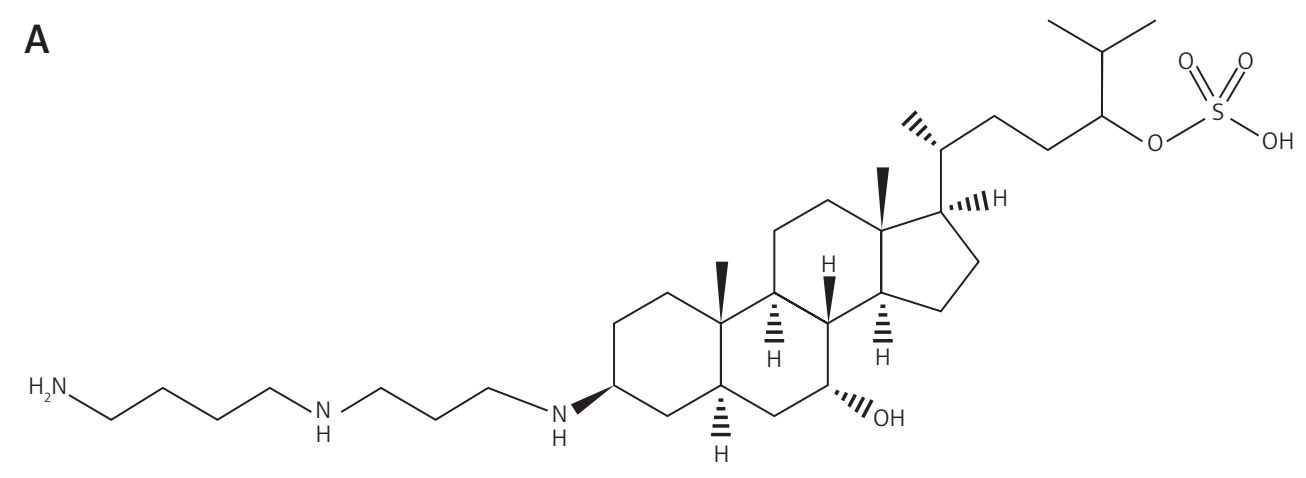

B
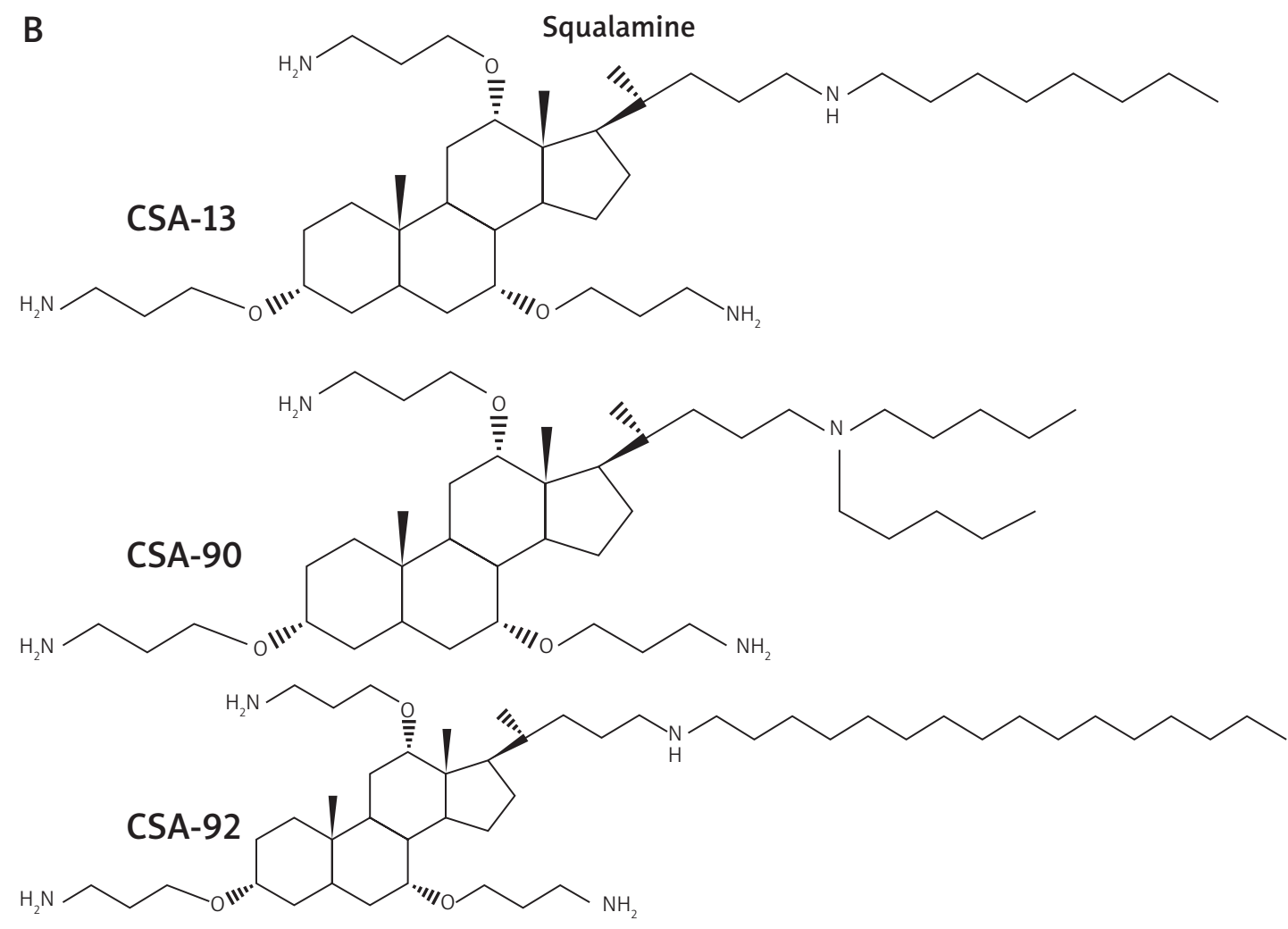

C

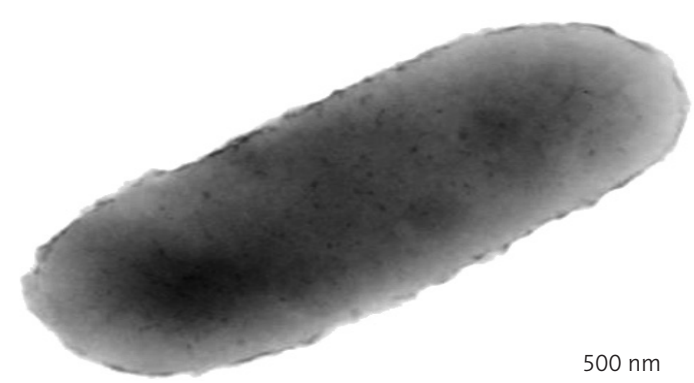

D

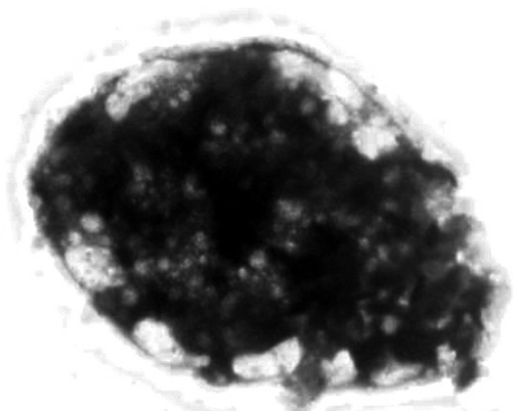

Figure 1. Squalamine: aminosterol molecules with potent broad spectrum of bactericidal activity isolated from tissues of the dogfish shark Squalus acanthias by Dr. Michael Zasloff [13] (panel A). Lead molecules of ceragenin family (panel B). EM image of E. coli cells before (panel C) and after treatment with CSA-13 for $1 \mathrm{~h}$ at $37^{\circ} \mathrm{C}$ (panel D) 
quality of life, and to reduce exacerbations in infected patients [41]. Different studies suggest that ceragenins have strong potential for the development of new treatments for CF lung infections. The synergy of antibiotics with molecules contributing to innate immunity is an additional approach to fight multi-resistant bacteria [42]. In addition to Pseudomonas aeruginosa, other common pathogens of CF lung infections include: Staphylococcus aureus, Haemophilus influenzae, Stenotrophomonas maltophilia, and Burkholderia species. All are susceptible to ceragenin treatment in vitro [19, 43-45].

In CF airways, $P$. aeruginosa infection persists in biofilm form. Biofilm formation protects the aggregated, biopolymer-embedded bacteria from antibiotic treatments and host immunity [46]. Regardless of the morphology of the biofilm, its formation starts with the adhesion of bacterial cells. This process depends to some extent on the interaction overcoming any repulsive forces between microorganisms and components of the extracellular environment. Natural negatively charged biopolymers like DNA and F-actin released from host cells were recently identified as important factors stimulating $P$. aeuginosa biofilm growth [47] and are also a potential target to prevent biofilm formation $[48,49]$. The antibacterial activity of ceragenins is not affected by DNA or F-actin, which are present in high concentration in cystic fibrosis airway sputum [43]. Combining ceragenins with classical antibiotics to fight resistant $P$. aeruginosa infections is a potential approach to this problem [50]. Bozkurt-Guzel et al. presented in vitro interactions of CSA-13 in combination with colistin, tobramycin, and ciprofloxacin against $P$. aeruginosa strains using a microbroth checkerboard. Their results showed synergistic interactions of CSA-13-colistin (54\% of tested strains), whereas the least synergistic interactions were observed with the CSA-13-tobramycin (25\% of tested strains). CSA-13colistin is shown to be the most effective combination, and the frequency of synergistic interactions in this combination showed significant statistical differences from CSA-13-tobramycin and colistin-ciprofloxacin. This is the first study associating CSA-13 with colistin against $P$. aeruginosa strains isolated from CF patients. Nagat et al. showed that CSA-13 effectively kills ensconced cells within established biofilms, in addition to just on the surface [51]. A low concentration of CSA-13 inhibits the formation of a biofilm by $P$. aeruginosa through electrostatic interaction [12]. Therefore, CSA-13 has bactericidal activity against $P$. aeruginosa even in mature biofilms, and appears to be a good candidate for further investigations of the treatment involving biofilms of $P$. aeruginosa strains in CF patients [52].

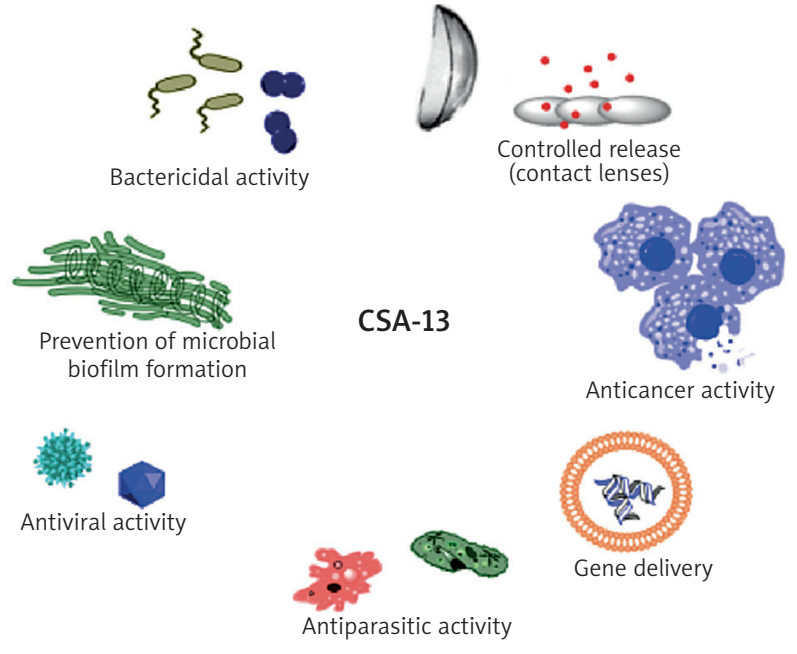

Figure 2. The various potential applications of ceragenin

\section{Conclusions}

Ceragenins are a promising class of molecules for the development of new treatments against infections caused by multidrug-resistant pathogens including resistant strains of $P$. aeruginosa within a biofilm.

\section{References}

1. Khanna S, Tosh PK. A clinician's primer on the role of the microbiome in human health and disease. Mayo Clin Proc 2014; 89: 107-14.

2. Shoham S, Shah PD. Impact of multidrug-resistant organisms on patients considered for lung transplantation. Infect Dis Clin North Am 2013; 27: 343-58.

3. Calfee DP. Multidrug-resistant organisms in dialysis patients. Semin Dial 2013; 26: 447-56.

4. Zignol M, Dara M, Dean AS, et al. Drug-resistant tuberculosis in the WHO European Region: an analysis of surveillance data. Drug Resist Updat 2013; 16: 108-15.

5. Zumla A, Raviglione M, Hafner R, von Reyn CF. Tuberculosis. N Engl J Med 2013; 368: 745-55.

6. Mshana SE, Matee M, Rweyemamu M. Antimicrobial resistance in human and animal pathogens in Zambia, Democratic Republic of Congo, Mozambique and Tanzania: an urgent need of a sustainable surveillance system. Ann Clin Microbiol Antimicrob 2013; 12: 28.

7. Kang CI, Song JH. Antimicrobial resistance in Asia: current epidemiology and clinical implications. Infect Chemother 2013; 45: 22-31.

8. Mathur P, Singh S. Multidrug resistance in bacteria: a serious patient safety challenge for India. J Lab Physicians 2013; 5: 5-10.

9. Salles MJ, Zurita J, Mejía C, et al. Resistant gram-negative infections in the outpatient setting in Latin America. Epidemiol Infect 2013; 141: 2459-72.

10. Paphitou NI. Antimicrobial resistance: action to combat the rising microbial challenges. Int J Antimicrob Agents 2013; 42 Suppl: S25-8. 
11. Worthington RJ, Melander C. Combination approaches to combat multidrug-resistant bacteria. Trends Biotechnol 2013; 31: 177-84.

12. Nagant C, Feng Y, Lucas B, et al. Effect of a low concentration of a cationic steroid antibiotic (CSA-13) on the formation of a biofilm by Pseudomonas aeruginosa. J Appl Microbiol 2011; 111: 763-72.

13. Moore KS, Wehrli S, Roder H, et al. Squalamine: an aminosterol antibiotic from the shark. Proc Natl Acad Sci U S A 1993; 90: 1354-8

14. Zasloff M. Magainins, a class of antimicrobial peptides from Xenopus skin: isolation, characterization of two active forms, and partial cDNA sequence of a precursor. Proc Natl Acad Sci U S A 1987; 84: 5449-53.

15. Zasloff M. Antimicrobial peptides in health and disease. N Engl J Med 2002; 347: 1199-200.

16. Ding B, Taotofa U, Orsak T, et al. Synthesis and characterization of peptide-cationic steroid antibiotic conjugates. Org Lett 2004; 6: 3433-6.

17. Epand RM, Epand RF, Savage PB. Ceragenins (cationic steroid compounds), a novel class of antimicrobial agents Drug News Perspect 2008; 21: 307-11.

18. Pollard JE, Snarr J, Chaudhary V, et al. In vitro evaluation of the potential for resistance development to ceragenin CSA-13. J Antimicrob Chemother 2012; 67: 2665-72.

19. Lai XZ, Feng Y, Pollard J, et al. Ceragenins: cholic acidbased mimics of antimicrobial peptides. Acc Chem Res 2008; 41: 1233-40.

20. Van Bambeke F, Mingeot-Leclercq MP, Struelens MJ, Tulkens PM. The bacterial envelope as a target for novel anti MRSA antibiotics. Trends Pharmacol Sci 2008; 29: 124-34.

21. Bellini AM, Vertuani G, Quaglio MP, Cavazzini G. Bile acid derivatives with antimicrobial activity. Farmaco Sci 1979; 34: 967-78.

22. Zanetti M, Gennaro R, Scocchi M, Skerlavaj B. Structure and biology of cathelicidins. Adv Exp Med Biol 2000; 479: 203-18.

23. Bucki R, Pastore JJ, Randhawa P, et al. Antibacterial activities of rhodamine B-conjugated gelsolin-derived peptides compared to those of the antimicrobial peptides cathelicidin LL37, magainin II, and melittin. Antimicrob Agents Chemother 2004; 48: 1526-33.

24. Savage PB, Li C, Taotafa U, et al. Antibacterial properties of cationic steroid antibiotics. FEMS Microbiol Lett 2002; 217: $1-7$.

25. Deng G, Dewa T, Regen SL. A synthetic ionophore that recognizes negatively charged phospholipid membranes. J Am Chem Soc 1996; 118: 8975-6.

26. Chin JN, Jones RN, Sader HS, et al. Potential synergy activity of the novel ceragenin, CSA-13, against clinical isolates of Pseudomonas aeruginosa, including multidrugresistant P. aeruginosa. J Antimicrob Chemother 2008; 61: 365-70.

27. Chin JN, Rybak MJ, Cheung CM, Savage PB. Antimicrobial activities of ceragenins against clinical isolates of resistant Staphylococcus aureus. Antimicrob Agents Chemother 2007; 51: 1268-73.

28. Leszczynska K, Namiot A, Fein DE, et al. Bactericidal activities of the cationic steroid CSA-13 and the cathelicidin peptide LL-37 against Helicobacter pylori in simulated gastric juice. BMC Microbiol 2009; 9: 187.

29. Bozkurt-Guzel C, Savage PB, Akcali A, Ozbek-Celik B. Potential synergy activity of the novel ceragenin, CSA-13, against carbapenem-resistant Acinetobacter baumannii strains isolated from bacteremia patients. Biomed Res Int 2014; 2014: 710273.

30. Isogai E, Isogai $\mathrm{H}$, Takahashi $\mathrm{K}$, et al. Ceragenin CSA-13 exhibits antimicrobial activity against cariogenic and periodontopathic bacteria. Oral Microbiol Immunol 2009; 24: 170-2.

31. Howell MD, Streib JE, Kim BE, et al. Ceragenins: a class of antiviral compounds to treat orthopox infections. J Invest Dermatol 2009; 129: 2668-75.

32. Lara D, Feng Y, Bader J, et al. Anti-trypanosomatid activity of ceragenins. J Parasitol 2010; 96: 638-42.

33. Hoppens MA, Wheeler ZE, Qureshi AT, et al. Maghemite, silver, ceragenin conjugate particles for selective binding and contrast of bacteria. J Colloid Interface Sci 2014; 413: 167-74.

34. Gu X, Jennings JD, Snarr J, et al. Optimization of ceragenins for prevention of bacterial colonization of hydrogel contact lenses. Invest Ophthalmol Vis Sci 2013; 54: 6217-23.

35. Sinclair KD, Pham TX, Williams DL, et al. Model development for determining the efficacy of a combination coating for the prevention of perioperative device related infections: a pilot study. J Biomed Mater Res B Appl Biomater 2013; 101: 1143-53.

36. Williams DL, Sinclair KD, Jeyapalina S, Bloebaum RD. Characterization of a novel active release coating to prevent biofilm implant-related infections. J Biomed Mater Res B Appl Biomater 2013; 101: 1078-89.

37. Sinclair KD, Pham TX, Farnsworth RW, et al. Development of a broad spectrum polymer-released antimicrobial coating for the prevention of resistant strain bacterial infections. J Biomed Mater Res A 2012; 100: 2732-8.

38. Kichler A, Leborgne C, Savage PB, Danos O. Cationic steroid antibiotics demonstrate DNA delivery properties. J Control Release 2005; 107: 174-82.

39. Kuroda K, Fukuda T, Okumura K, et al. Ceragenin CSA13 induces cell cycle arrest and antiproliferative effects in wild-type and p53 null mutant HCT116 colon cancer cells. Anticancer Drugs 2013; 24: 826-34.

40. Saha S, Savage PB, Bal M. Enhancement of the efficacy of erythromycin in multiple antibiotic-resistant gramnegative bacterial pathogens. J Appl Microbiol 2008; 105: 822-8.

41. Dhooghe B, Noël S, Huaux F, Leal T. Lung inflammation in cystic fibrosis: pathogenesis and novel therapies. Clin Biochem 2014; 47: 539-46.

42. Rosenthal KL. Tweaking innate immunity: the promise of innate immunologicals as anti-infectives. Can J Infect Dis Med Microbiol 2006; 17: 307-14.

43. Bucki R, Sostarecz AG, Byfield FJ, et al. Resistance of the antibacterial agent ceragenin CSA-13 to inactivation by DNA or F-actin and its activity in cystic fibrosis sputum. J Antimicrob Chemother 2007; 60: 535-45.

44. Leszczynska K, Namiot D, Byfield FJ, et al. Antibacterial activity of the human host defence peptide LL-37 and selected synthetic cationic lipids against bacteria associated with oral and upper respiratory tract infections. J Antimicrob Chemother 2013; 68: 610-8.

45. Rodríguez-Rojas A, Oliver A, Blázquez J. Intrinsic and environmental mutagenesis drive diversification and persistence of Pseudomonas aeruginosa in chronic lung infections. J Infect Dis 2012; 205: 121-7. 
46. Alhede M, Bjarnsholt T, Givskov M. Pseudomonas aeruginosa biofilms: mechanisms of immune evasion. Adv Appl Microbiol 2014; 86: 1-40.

47. Walker TS, Tomlin KL, Worthen GS, et al. Enhanced Pseudomonas aeruginosa biofilm development mediated by human neutrophils. Infect Immun 2005; 73: 3693-701.

48. Parks QM, Young RL, Poch KR, et al. Neutrophil enhancement of Pseudomonas aeruginosa biofilm development: human F-actin and DNA as targets for therapy. J Med Microbiol 2009; 58: 492-502.

49. Moreau-Marquis S, Stanton BA, O’Toole GA. Pseudomonas aeruginosa biofilm formation in the cystic fibrosis airway. Pulm Pharmacol Ther 2008; 21: 595-9.

50. Döring G, Conway SP, Heijerman HG, et al. Antibiotic therapy against Pseudomonas aeruginosa in cystic fibrosis: a European consensus. Eur Respir J 2000; 16: 749-67.

51. Nagant C, Pitts B, Stewart PS, et al. Study of the effect of antimicrobial peptide mimic, CSA-13, on an established biofilm formed by Pseudomonas aeruginosa. Microbiologyopen 2013; 2: 318-25.

52. Bozkurt-Guzel C, Savage PB, Gerceker AA. In vitro activities of the novel ceragenin CSA-13, alone or in combination with colistin, tobramycin, and ciprofloxacin, against Pseudomonas aeruginosa strains isolated from cystic fibrosis patients. Chemotherapy 2011; 57: 505-10

\section{Address for correspondence:}

\section{Prof. Robert Bucki}

Department of Pathophysiology and Infection Microbiology Faculty of Health Sciences Jan Kochanowski University ul. IX Wieków 19, Kielce, Poland Fax: +48 857485483

E-mail: mikro.nano@umb.edu.pl 